\title{
JOHAN HUIZINGA
}

Leopoid v. Rank afirmou em 1862: "Denn nicht dazu sind uns die grossen Lehrer gegeben, um an ihren Worten festzuhaiten und sie zu wiederholen: der Geist allein ist es auch in der Wissens̀chaft, welcher lebendig macht. Das Verdienst grosser Werke beruht darauf, dass sie neue Bahnen weisen und sie mit Erfolg einschlagen. Sie beruhen auf dem Besitz der erworbenen Gelehrsamkeit, aber indem sie die Grundlagen untersuchen und frueher vergessene Momente zur Anschauung bringen, geben sie dem untersuchenden Geist eine Richtung auf umfassendere Wahrheit und tiefere Erkenntnis des Gegenstandes. (Pois não foi para que nós nos prenđêssemos às suas palavras e as repetissemos, que nos foram dados os grandes mestres. E' o espírito sòzinho, também nas ciências, que vivifica. O mérito das grandes obras fundamenta-se na indicação de novos rumos, que elas seguem indepedentemente e ccroadas do melhor sucesso. Baseiam-se em conhecimento adquirido, mas ao examinar as suas fontes e discutir assuntos anteriormente esquecidos, proporcionam ao espírito perscrutador a visão de uma verdade mais complexa e mais profundo conhecimento do assunto em si). E é no sentido de Ranke que aqui queremos esboçar algumas considerações sôbre o grande escritor holandês Johan Huizinga, falecido em 1945. Se bem que citado freqüentemente por seu Herfstiij aer Middeleeuwen (1919) que no Brasil pode ser lido nas traduções francesa (Le Déclin du Moyen-Âge) e espanhola (el Otoño de la Edad Media) ou então pelo Homo Ludens, proeve centr bepaling van het spelelemente der cultuur (Homo Ludens, o Jôgo como elemento da História), continuam as obras de Huizinga a não obter de estudioscs e diletantes a atenção que merecem. Huizinga é um historiador no sentido mais amplo, quer dizer um crítico da cultura. Em mais de 150 obras percorreu o caminho extenso, desde estudioso especializado em assuntos indianos, até de historiador mais prcfundo que o Ocidente apresentou resses últimos anos.

Não é possível abranger em poucas linhas tôdas as facetas da investigação e dos ensinamentos de Johan Huizinga, mas desejamos aqui esboçar brevemente a sua grande obra de crítico da cultura, daquilo que os alemães chamam de Kulturhistoriker. Aos 41 anos foi designado para a cátedra de História Universal e Geografia Histórica de Leiden, uma đas mais antigas universidades ho- 
landesas, após ter ocupado durante 9 anos cátedra semelhante na Universidade de Groningen. E foi nos primeiros anos de sua atividade de Leiden que Huizinga publica sua obra monumental: O Outono da Idade Média.

Se êste livro, em sua primeira concepção, deveria apenas narrar a história da Burgúndia, veio a ser mais tarde uma obra em que está generalizada a idéia central de Huizinga: "O fim da Idade Média náo é a alvorada de uma éra nova, é - isto sim - crepúsculo de uma época passada". Esta opinião, que deveria derramar luz nova sôbre o caráter dos XIV e XV séculos na França e nos Países-Baixos, tornou-se o leitmotiv da obra e do pensamento histórico de Huizinga.

Especialmente interessante é considerar que Huizinga hauria êsses novos 'conhecimentos "da arte medieval", e em particular da arte de van Eyck e seus contemporâneos. Isto é a evidência de como se distanciavam os sentimentos de Huizinga das opiniões então dominantes na história da arte, que na expressão artística daquale tempo julgava ver o início de uma renascença nórdica.

Huizinga trata no seu Outono da Idace Média da mesma época na Burgúndia, que Jacob Burckhardt analiscu em sua Cultura da Renascença na Itália. Mas como são diferentes as duas concepções! Não apenas pelo fato de Huizinga, como o mais moço, considerar sob ângulo diverso a relaşão entre a Idade Média e a Renascença, sem levar em consideração a forma política do estado, interessando-se principalmente pela arte e pela literatura! Aquilo que, mais que tudo isto, separa os dois grandes autores, é a profunda diferença e divergência quanto ao sentimento da época a da própria vida. Burckhardt esboça uma sociedade que, potente, procura elevar-se, Huizinga uma cultura tardia e apurada, cujo espírito se afasta da verdade crua para refugiar-se em um mundo de esplendorosa fantasia. Em épo:a em que a Europa já tinha tomado consciência de outro porvir, continua a sociedade aristocrática da Burgúndia, em estilização completa, a desミmpenhar o seu jôgo dos ideais medievais de cavaleiro e santo, de amor e asceticismo. Mas ao som dêste jôgo tornam-se perceptíveis as notas agudas da verdade, transfcrmando tudo $\mathrm{em}$ dissonância violenta. Daí a atmosfera de outono, que paira sôbre tóda a época, e que o leitor encontra já no título da obra.

Mas um livro tão fora do comum não é imediatamente compreendido. Quem nele procurar a história cultural da Burgúndia, fica tão decepzionado quanto aquêle que pretende ver o trabaiho verdadeiro do historiador na descrição pura e simples dos acontecimentos. Trata-se do marco fundamental da descrição histórico cultural européia, e foi o Outorio da Idade Méaia, que espalhou a fama do historiador de Leiden.

Este €şírito gigantesco não poderia permanecer imóvel perante a evolução histórica de seu próprio tempo. Ainda em seus 
primeiros anos de professor em Leiden, concomitante com seu trabalho sôbre a Idade Média, começaram a exercer influência notável sôbre Huizinga as questões da vida espiritual americana, e assim publica já em 1918 seu Mensch en menigte in Amerika ( $O$ homem e a massa popular na América). Quando Huizinga escreveu êste livro, ainda não havia tomado contacto pessoal com os Estados Unidos da América do Norte, mas apesar disto dava tão exata e profunda apreciação sôbre êsse gigantesco país, que um crítico da época afirmou que "através de suas páginas sente-se a essência do espírito americano". Seu segundo livro sôbre os Estados Unidos, Amerika, levend en denkend (Vida e pensamento na América) fundamenta-se em experiência pessoal, é o diário de sua viagem aos Estados Unidos em 1926. E esta viagem permitiuthe não apenas travar contacto direto com historiadores norte-americancs, mas Huizinga conheceu também os mais destacados economistas, sociólogos e psicólogos yankees. E' assim que afirma em seus Wege der Kulturgeschichte (Caminhos da História da Cultura): "Há algo de brilhante e comovente na lembrança dessas gentilezas simples e alegres, dessa benevolência claramente expressa, dessa falta de fingimento, pose e convencimento. A representação do indivíduo submerge na recordação da generalidade, como árvores no murmúrio de uma floresta". Mas apesar desta aceitação, aparentemente ilimitada, do modus vivendi norte-americano, sentiu-se êste grande holandês, representante da talvez última geração especificamente européia, chocado pela posição anti-histórica e anti-metafísica do espírito médio estadunidense, declarando "preferir habitar nos territórios dominados pelas exteriorizações da loucura e do temor da cultura antiga, do que na "terra prometida" da perfeição social.

$E$ é assim que o eminente crítico da cultura, Johan Huizinga, abrange os terrenos e as épocas mais diversas, mas sempre domina e encanta, porque a sua crítica é objetiva e construtiva. Quer fale da Idade IMédia ou de nossa irritada e debilitada atualidade, encontra sempre uma palavra satisfatória, uma explicação precisa, um expediente capaz de provocar uma mudança salutar. Assim, são muito bem escolhidas as palavras de Gabriel Hanotaux:

"M. Huizinga nous tient toujours en son laboratoire; et nous assistons, par l'analyse des infiments petits, à une reconstittition après dissection." 